\title{
АЛГОРИТМ РЕАЛІЗАЦІї ТА ЗАХОДИ АНТИКРИЗОВОГО УПРАВЛІННЯ ПІДПРИЕМСТВОМ
}

\author{
Онісіфорова В.Ю., канд. екон. наук, доцент \\ Харківський національний автомобільно-дорожній університет \\ Болотова Т.М., канд. екон. наук, доцент \\ Харківський торговельно-економічний коледж КНТЕУ
}

Постановка проблеми. Економічна криза, яка все більше охоплює світову та національні економіки більшості країн, призводить до подальшого погіршення умов функціонування підприємств та суттєво підвищує ймовірність виникнення криз в різних напрямках їх діяльності. Швидкість прояву таких криз на сьогодні визначається лише накопиченим підприємствами в попередні періоди «запасом міцності». Все це робить проблему антикризового управління надзвичайно актуальною для дослідження в сучасних умовах розвитку економіки України.

Аналіз останніх досліджень та публікацій. Темі антикризового управління підприємством присвятила свої роботи дуже значна кількість вітчизняних та закордонних дослідників. В своїх дослідженнях автори фокусують свою увагу на дослідженні сутності антикризового управління [1-4], дослідженні окремих його теоретичних аспектів, формуванню ефективних стратегій та методів [5, 6], особливостях реалізації в умовах підприємств малого та середнього бізнесу [7] та окремих галузях промисловості [8].

Невирішені складові загальної проблеми. Не зважаючи на велику кількість досліджень, вимагає більш грунтовного дослідження проблема побудови ефективного алгоритму прийняття управлінського рішення 3 антикризового управління підприємством та пошуку дієвих заходів його реалізації.

Формулювання цілей статті. Метою статті $є$ формування алгоритму реалізації антикризового управління підприємством та переліку його актуальних заходів.

Виклад основного матеріалу дослідження. Антикризове управління на сьогодні, безумовно, повинно бути присутнім в системі менеджменту будьякого вітчизняного підприємства, бо його мета - попередження виникнення кризи в його діяльності або мінімізація іiі негативних наслідків, якщо розгортання кризи на підприємстві попередити не вдалося. Тобто, 3 точки зору змісту антикризового управління, його можна розглядати відносно факту виникнення кризи як попереджуючий захід, або як захід 3 нейтралізації наслідків. Отже, слід розуміти чіткий алгоритм прийняття управлінських рішень в даній підсистемі управління підприємством.

Ефективне рішення з антикризового управління підприємством, на наш погляд, повинне проходити під час своєї реалізації наступні етапи [9]: 
1) Стартовим моментом при прийнятті будь-якого управлінського рішення на підприємстві є збір та первинна обробка якісної, достовірної та достатньої інформації. Джерелами інформації в даному випадку мають бути дані бухгалтерського та управлінського обліку підприємства.

2) Аналіз фінансових показників підприємства на основі даних обліку 3 метою оцінювання його поточного стану та прогнозування ймовірності настання кризи.

3) Оцінка наявності в діяльності підприємства вже існуючої кризи, яка потребує запровадження антикризових заходів.

4) У разі, якщо поточної кризи на підприємстві немає, оцінювання вірогідності розгортання кризи в майбутньому при збереженні поточних показників діяльності. При цьому важливим є визначитися з тим, яку саме ймовірність власник або менеджмент підприємства вважають припустимою, бо така вірогідність кризи постійно присутня в діяльності будь-якого підприємства.

5) У разі, якщо криза в діяльності підприємства наявна, або за прогнозними показниками вірогідність настання кризи в майбутньому вища за припустиму, слід визначитися 3 загальною стратегією антикризового управління, тобто напрямком та цілями, які менеджмент підприємства планує досягти в результаті реалізації антикризових заходів. Тобто в загальному вигляді це має бути стратегія подолання кризи або стратегія недопущення кризи [10].

6) Розробка конкретних заходів з реалізації обраної антикризової стратегії 3 врахуванням їх відповідності параметрам внутрішнього i зовнішнього середовища підприємства, оптимальної структури майна i зобов'язань, оптимального співвідношення доходів та витрат, оптимального співвідношення надходження і відтоків грошових коштів [10].

7) Реалізація заходів антикризової стратегії управління.

8) Оцінка ефективності реалізованих заходів 3 точки зору досягнення цілей антикризового управління. При цьому на підприємстві може бути два варіанти розвитку подій відповідно до ефективності запроваджених заходів вихід 3 кризи або іiі попередження, якщо антикризова стратегія була ефективною, та майбутня ліквідація підприємства, якщо подолати негативні наслідки кризи за допомогою антикризових заходів виявилося неможливим.

Отже, контрольними етапами в процесі реалізації антикризового управління підприємством є:

- діагностика наявності кризи;

- визначення ймовірності настання кризи, вищої за рівень, припустимий менеджментом або власником;

- оцінка ефективності заходів антикризової стратегії підприємства.

Принциповий алгоритм реалізації антикризового управління підприємством 3 зазначенням контрольних етапів прийняття та реалізації 
відповідних управлінських рішень для більшої наочності подано в графічному вигляді на рис. 1.

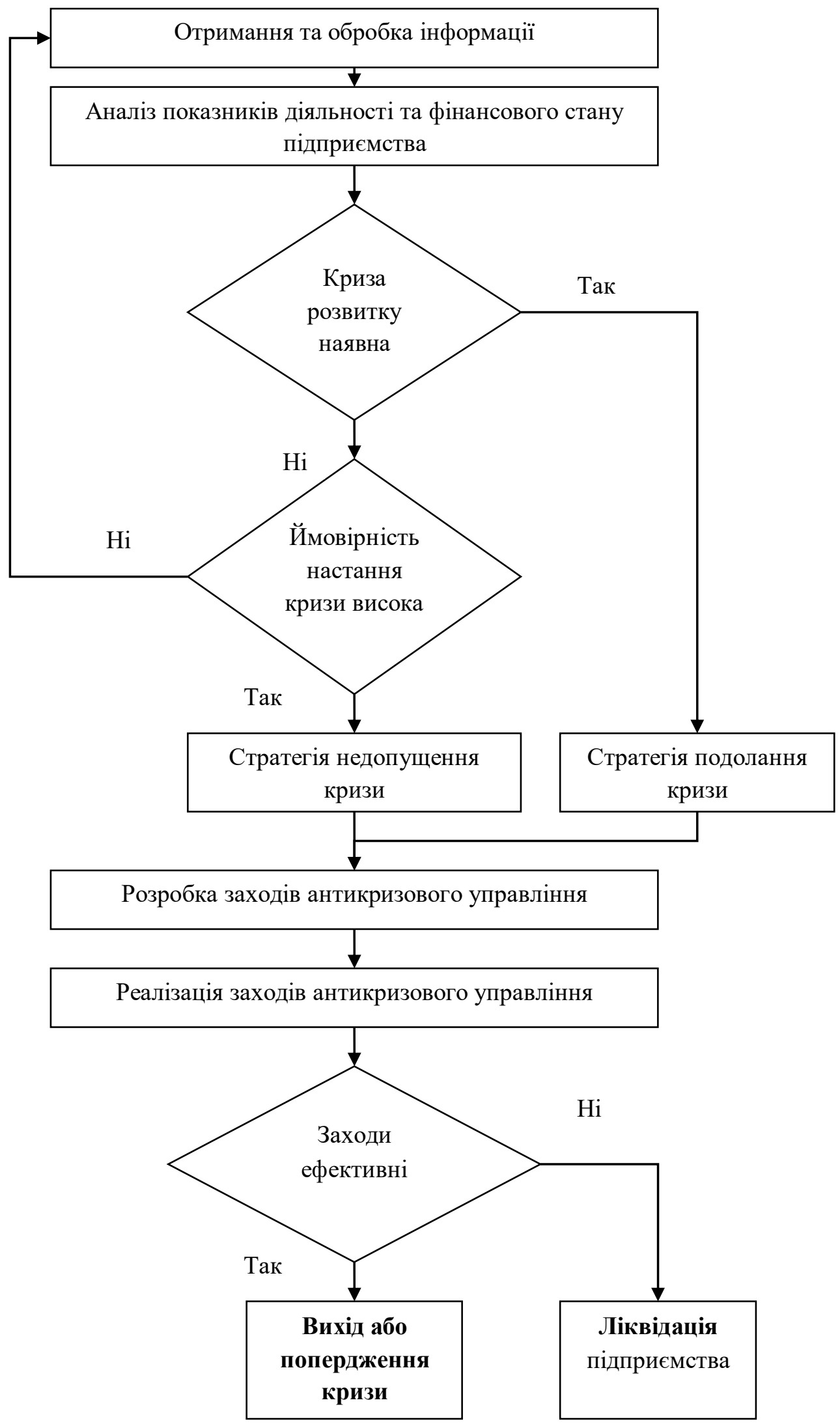

Рис. 1. Алгоритм реалізації антикризового управління підприсмством 
Слід також зазначити, що відповідно до актуального широкого погляду на сутність та зміст антикризового управління підприємством, критеріями ефективності реалізації антикризової стратегії мають бути не лише поліпшення показників фінансового стану підприємства, але й забезпечення умов для його розвитку, підвищення ефективності використання наявних ресурсів.

В алгоритмі реалізації антикризового управління одним 3 найважливіших етапів $\epsilon$ формування переліку його ефективних заходів. В працях за досліджуваною темою можна виокремити наступні 3 них $[1,5,6]$ :

- оптимізація статей витрат підприємства та скорочення їх обсягу;

- оптимізація податкового навантаження;

- ефективна кадрова політика;

- ефективна маркетингова стратегія та використання ії потенціалу;

- впровадження ефективної системи управління підприємством в цілому;

- оптимізація системи планування;

- оптимізація бюджетування;

- контроль чистого грошового потоку;

- підвищення якості інформації, тощо.

Комбінація заходів з зазначеного переліку, зазвичай, $\epsilon$ ефективною в системі антикризового управління підприємством та дозволяє досягти його цілей.

Висновки 3 проведеного дослідження. Антикризове управління на сьогодні має бути обов'язковим елементом системи управління підприємством. Така підсистема управління дозволяє не лише подолати негативні наслідки кризи в діяльності підприємства, але й попередити ії появу за рахунок вчасного оцінювання вірогідності іiі настання. Впровадження ефективної системи антикризового управління дозволяе не лише уникати кризи неплатоспроможності, але й дозволяє створити умови для розвитку та підвищення ефективності роботи підприємства, ефективного використання всіх видів ресурсів.

\section{Перелік посилань}

1. Банера Н. П. Антикризове управління як один із шляхів виходу із фінансової кризи. Глобальні та національні проблеми економіки. Миколаїв, 2016. №10. C. 266-269.

2. Борзенко В. I. Антикризове управління: навч. посібник. X.: Видавництво Іванченка, 2016. 232 с.

3. Коляденко I. I., Кавтиш О. П. Наукові підходи до сутності антикризового управління. Науково-виробничий журнал «Бізнес-навігатор». Херсон, 2018. №2-2(45). С. 7-10.

4. Лігоненко Л. Антикризове управління підприємством: теоретикометодологічні засади та практичний інструментарій: монографія. Київ: Київ. нац. торг.-екон. ун-т, 2001. 580 с. 
5. Морозов С. Ю. Антикризові заходи в системі управління підприємством. Держава та регіони. Серія: Економіка та підприємництво. 2018. № 3. C. 114-120.

6. Рамазанов С. К., Степаненко О. П., Тимашова Л. А. Методи антикризового управління: монографія. Луганськ: Вид-во СНУ ім В. Даля, 2004. 192 c.

7. Мирошниченко Ю. В., Вдовіченко А. С. Антикризове управління на підприємствах малого та середнього бізнесу. Проблеми $і$ перспективи розвитку підприємництва. Харків, 2020. №25. С. 119-132. DOI: http://doi.org/10.30977/PPB.2226-8820.2020.24.0.119.

8. Ткачук Г. Ю. Стратегії антикризового управління підприємствами металургійної промисловості. МНУ ім В. О. Сухомлинського. Глобальні та національні проблеми економіки. 2018. № 21. С. 416-420

9. Дмитрієв I. А., Близнюк А. О., Онісіфорова В. Ю. Управління економічною безпекою автотранспортного підприємства: монографія. Харків, 2014. $216 \mathrm{c}$.

10. Костецький В. Формування стратегії антикризового управління підприємством. Економічний аналіз. 2011. Вип. 8. Ч. 2. С. 208-211.

\section{References}

1. Banera, N. P. (2016), Anti-crisis management as one of the ways out of the financial crisis [Antykryzove upravlinnia yak odyn iz shliakhiv vykhodu iz finansovoi kryzy], Global and national economic problems, Mykolayiv, No. 10, P. 266-269.

2. Borzenko, V. I. (2016), Anti-crisis management [Antykryzove upravlinnya: navch. posibnyk], training manual, Kh.: Publishing House Ivanchenko, 232 p.

3. Kolyadenko, I. I., Kavtysh, O. P. (2018), Scientific approaches to the essence of crisis management [Naukovi pidkhody do sutnosti antykryzovoho upravlinnia], Research and production magazine "Business Navigator", Kherson, No. 2-2 (45), P. 7-10.

4. Ligonenko, L. (2001), Anti-crisis management of the enterprise: theoretical and methodological principles and practical tools: monograph [Antykryzove upravlinnia pidpryiemstvom: teoretyko-metodolohichni zasady ta praktychnyi instrumentarii: monohrafiia], Kyiv, 580 p.

5. Morozov, Ye. Yu. (2018), "Anti-crisis measures in the enterprise management system" ["Antykryzovi zakhody v systemi upravlinnya pidpryyemstvom"], State and regions. Series: Economics and Business, No. 3, P. 114-120.

6. Ramazanov, S. K., Stepanenko, O. P., Timashova, L. A. (2004), Methods of crisis management [Metody antykryzovoho upravlinnya: monohrafiya], monograph, Publishing center of V. Dahl EUNU, Lugansk, 192 p.

7. Miroshnychenko, Yu.V., Vdovichenko, A.S. (2020), Anti-crisis management in small and medium enterprises [Antykryzove upravlinnia na pidpryiemstvakh 
maloho ta serednoho biznesu], Problems and perspectives of entrepreneurship development, Kharkiv, No. 25, P. 119-132.

8. Tkachuk, H. Yu. (2018), "Anti-crisis management strategies for enterprises of metallurgical industry" ["Stratehii Antykryzovoho upravlinnia pidpryiemstvamy metalurhiinoi promyslovosti"], Global and national problems of economy, Mykolaiv V.O. Sukhomlynskyi national university, No. 21, P. 416-420.

9. Dmytriiev, I., Blyzniuk, A., Onisiforova, V. (2014), Management of economic safety of motor transport enterprise: monograph [Upravlinnia ekonomichnoiu bezpekoiu avtotransportnoho pidpryiemstva: monohrafiia], Kharkiv, 2014, 216 p.

10. Kostetskyi, V. (2011), "Forming a Strategy for Anti-Crisis Enterprise Management" ["Formuvannya stratehiyi Antykryzovoho upravlinnya pidpryyemstvom"], Economic Analysis, No. 8, Part 2, P. 208-211.

\section{РЕФЕРАТИ РЕФЕРАТЫ ABSTRACTS}

\section{УДК 658.15; JEL Classification: М21}

Онісіфорова В.Ю., Болотова Т.М. АЛГОРИТМ РЕАЛІЗАЦІї ТА ЗАХОДИ АНТИКРИЗОВОГО УПРАВЛІННЯ ПІДПРИЕМСТВОМ

Мета. Формування алгоритму реалізації антикризового управління підприємством та переліку його актуальних заходів. Методика дослідження. В ході дослідження використовувалися методи аналізу і синтезу, метод логічного аналізу. Інформаційними ресурсами дослідження $\epsilon$ електронні інформаційні ресурси і матеріали періодичних видань. Результати. Антикризове управління повинне бути присутнім в системі менеджменту будьякого вітчизняного підприємства. Отже, слід розуміти чіткий алгоритм прийняття управлінських рішень в даній підсистемі управління підприємством. Ефективне рішення 3 антикризового управління підприємством повинне проходити під час своєї реалізації наступні етапи: збір та первинна обробка якісної, достовірної та достатньої інформації; аналіз фінансових показників підприємства; оцінка наявності в діяльності підприємства вже існуючої кризи; оцінювання вірогідності розгортання кризи в майбутньому; вибір загальної стратегії антикризового управління; розробка заходів 3 реалізації обраної антикризової стратегії; реалізація заходів антикризової стратегії управління; оцінка ефективності реалізованих заходів 3 точки зору досягнення цілей антикризового управління. В алгоритмі реалізації антикризового управління одним з найважливіших етапів $є$ формування переліку його ефективних заходів, якими можуть бути: оптимізація статей витрат підприємства та скорочення їх обсягу; оптимізація податкового навантаження; ефективна кадрова політика; ефективна маркетингова стратегія та використання іï потенціалу; впровадження ефективної системи управління підприємством в цілому; оптимізація системи планування; оптимізація бюджетування; контроль чистого грошового потоку; підвищення якості інформації. Наукова новизна. Сформовано алгоритм 
реалізації управлінського рішення з антикризового управління підприємством та уточнено перелік заходів антикризової стратегії підприємства. Практична значущість. Запропоновані висновки можуть бути використані керівниками та власниками підприємств при формування системи антикризового управління.

Ключові слова: антикризове управління підприємством; алгоритм антикризового управління; антикризова стратегія підприємства; заходи антикризового управління; ефективність управління.

\section{УДК 658.15; JEL Classification: M21}

Онисифорова В.Ю., Болотова Т.Н. АЛГОРИТМ РЕАЛИЗАЦИИ И МЕРОПРИЯТИЯ АНТИКРИЗИСНОГО ПРЕДПРИЯТИЕМ УПРАВЛЕНИЯ

Цель. Формирование алгоритма реализации антикризисного управления предприятием и перечня его актуальных мероприятий. Методика исследования. В ходе исследования использовались методы анализа и синтеза, метод логического анализа. Информационными ресурсами исследования являются электронные информационные ресурсы и материалы периодических изданий. Pезультаты. Антикризисное управление должно присутствовать в системе менеджмента любого отечественного предприятия. Поэтому следует понимать четкий алгоритм принятия управленческих решений в данной подсистеме управления предприятием. Эффективное решение по антикризисному управлению предприятием должно проходить при своей реализации следующие этапы: сбор и первичная обработка качественной, достоверной и достаточной информации; анализ финансовых показателей предприятия; оценка наличия в деятельности предприятия уже существующего кризиса; оценивания достоверности развертывания кризиса в будущем; выбор общей стратегии антикризисного управления; разработка мероприятий по реализации выбранной антикризисной стратегии; реализация мероприятий антикризисной стратегии управления; оценка эффективности реализованных мероприятий с точки зрения достижения целей антикризисного управления. В алгоритме реализации антикризисного управления одним из важнейших этапов является формирование перечня его эффективных мероприятий, которыми могут быть: оптимизация статей расходов предприятия и сокращение их объема; оптимизация налоговой нагрузки; эффективная кадровая политика; эффективная маркетинговая стратегия и использования ее потенциала; внедрение эффективной системы управления предприятием в целом; оптимизация системы планирования; оптимизация бюджетирования; контроль чистого денежного потока; повышение качества информации. Научная новизна. Сформирован алгоритм реализации управленческого решения по антикризисному управлению предприятием и уточнен перечень мероприятий антикризисной стратегии предприятия. Практическая значимость. Предложенные выводы могут быть использованы руководителями и 
собственниками предприятий при формировании системы антикризисного управления.

Ключевые слова: антикризисное управление предприятием; алгоритм антикризисного управления; антикризисная стратегия предприятия; меры антикризисного управления; эффективность управления.

UDC 658.15; JEL Classification: M21

Onisiforova V.Yu., Bolotova T.M. ALGORITHM OF IMPLEMENTATION AND WAYS OF THE ENTERPRISE ANTI-CRISIS MANAGEMENT

Purpose. Formation of the algorithm of the enterprise anti-crisis management realization and the list of its actual activities. Methodology of research. Methods of analysis and synthesis, the method of logical analysis were used in investigation. The informative resources of the study are electronic informative resources and periodical materials. Results. Crisis management should be presented in the management system of any domestic enterprise. Therefore, it is necessary to understand a clear algorithm for making management decisions in this subsystem of enterprise management. During implementation an effective solution for crisis management of the enterprise has to go through the following stages: collection and initial processing of quality, reliable and sufficient information; analysis of financial indicators of the enterprise; assessment of the crisis presence, which has already existed in the enterprise; assessment of the probability of a future crisis; choice of general strategy of crisis management; development of ways to implement the selected anti-crisis strategy; implementation of anti-crisis management strategy ways; assessment of the implemented ways affectivity in terms of achieving the objectives of crisis management. One of the most important stages in the algorithm of anti-crisis management realization is formation of the effective ways list. These ways can be: optimization of the enterprise expenses and reduction of their volume; tax burden optimization; effective personnel policy; effective marketing strategy and use of its potential; introduction of an effective management system of the enterprise in total; optimization of the planning system; budget optimization; net cash flow control; improving of the information quality. Originality. The algorithm of realization of the administrative decision about enterprise anti-crisis management is formed and the list of enterprise anti-crisis strategy ways is specified. Practical value. The proposed conclusions can be used by managers and owners of enterprises in the formation of crisis management system.

Key words: anti-crisis management of the enterprise, algorithm of anti-crisis management, anti-crisis strategy of the enterprise, ways of anti-crisis management, management efficiency. 


\section{Відомості про авторів / Сведения об авторах / About the Authors}

Онісіфорова Валентина Юріївна - кандидат економічних наук, доцент, Харківський національний автомобільно-дорожній університет, доцент кафедри економіки i підприємництва, м. Харків, Україна; e-mail: valentinaonisiforova @ gmail.com; ORCID ID: http://orcid.org/0000-0001-9899-8427. Моб. 099-499-14-28.

Онисифорова Валентина Юрьевна - кандидат экономических наук, доцент, Харьковский национальный автомобильно-дорожный университет, доцент кафедры экономики и предпринимательства, г. Харьков, Украина.

Onisiforova Valentyna - Candidate of Sciences (Economics), Associate Professor, Kharkov National Automobile and Highway University, Associate Professor at the Department of Economics and Entrepreneurship, Kharkiv, Ukraine.

Болотова Тетяна Миколаївна - кандидат економічних наук, доцент, Харківський торговельно-економічний коледж КНТЕУ, Голова ЦК економіки, управління та адміністрування, м. Харків, Україна; е-mail: tatabolotova1975@gmail.com; ORCID ID: http://orcid.org/0000-0003-1414-880X. Моб. (050)302-57-77.

Болотова Татьяна Николаевна - кандидат экономических наук, доцент, Харьковский торгово-экономический колледж КНТЭУ, Глава ЦК экономики, управления и администрирования, г. Харьков, Украина.

Bolotova Tatyana - Candidate of Sciences (Economics), Kharkov College of Trade and Economics KNTEU, Head of the Central Committee of Economics, Management and Administration, Kharkiv, Ukraine. 